\title{
P02-0 I. Elicitation of a humoral immune response towards non-immunogenic peptides using the transcriptional transactivator of HIV-I
}

\author{
A Gadzinski*, E Favre, S Turbant and M Leonetti
}

Address: Centre CEA Saclay, Gif sur Yvette, France

* Corresponding author

from AIDS Vaccine 2009

Paris, France. 19-22 October 2009

Published: 22 October 2009

Retrovirology 2009, 6(Suppl 3):P6 doi:10.1 186/I 742-4690-6-S3-P6

This abstract is available from: http://www.retrovirology.com/content/6/S3/P6

(c) 2009 Gadzinski et al; licensee BioMed Central Ltd.

\section{Background}

We previously showed that the transcriptional transactivator (Tat) of human immunodeficiency virus possesses the unusual ability to raise a humoral immune response in the absence of adjuvant. These observations prompted us to examine whether such a property can be used to raise an immune response against non-immunogenic peptides.

\section{Methods}

As we previously observed that the autoadjuvant property is controlled by a determinant located within the coreand cysteine-rich regions of the protein, we synthesized a Tat peptide (pTat) overlapping these two regions and investigated whether it can provide immunogenic properties to two peptides originating from diphtheria toxin (pDT) and from toxin alpha (pT). These two peptides that both contain a helper T-cell epitope but are nonetheless non-immunogenic in BALB/c mice were chemically synthesized in a free form or covalently associated with pTat. Then, to assess the ability to raise a humoral immune response, six groups of $\mathrm{BALB} / \mathrm{c}$ mice were injected twice at two weeks interval with pTatpT, pTatpDT, pT, pDT, pT + pTat and pT + pTat, respectively.

\section{Results}

The animals were bled 14 and 28 days after the second immunisation and the sera were incubated in 96 wells microtiter ELISA plates previously coated with either pT or pDT, in order to determine the anti-pT and anti-pDT antibody response. Significant antibody titers were measured in the sera from mice immunised with either pTatpT or pTatpDT, while no titers were found in the sera from animals immunised with either pDT or $\mathrm{pT}$ in the presence or absence of pTat.

\section{Conclusion}

Our results indicate that a humoral immune response can be raised towards non-immunogenic peptides using a peptide overlapping the determinant involved in the autoadjuvant property of Tat and that the phenomenon requires its covalent coupling to the peptide antigen. 